\title{
Comparative pharmacobotanic study and ethnopharmacological uses of the "Botones de oro" from Argentinean folk medicine
}

\author{
María A. Gette, ${ }^{1}$ Marta E. Petenatti, ${ }^{1}$ Luis A. Del Vitto, ${ }^{1}$ Susana Zacchino, ${ }^{2}$ \\ Elisa M. Petenatti*,1
}

\begin{abstract}
${ }^{1}$ Herbarium, Pharmacobotany and Pharmacognosy, Universidad Nacional de San Luis, Ejército de los Andes 950, 5700 San Luis, Argentina,

${ }_{2}^{2}$ Pharmacognosy, Universidad Nacional de Rosario, Suipacha 531, 2000 Rosario, Santa Fe, Argentina
\end{abstract}

\begin{abstract}
RESUMO: "Estudos farmacobotânicos comparativos e utilizações ethnopharmacológicas do "botões d'ouro" da medicina popular Argentina". As partes aéreas de seis plantas argentinas - conhecidas geralmente como "botões d'ouro" - são usadas indistintamente na medicina popular ou para obter remédios ervais e fitoterápicos. No entanto, estas entidades pertencem a três gêneros da tribo Helenieae (Asteraceae): Gaillardia, Helenium e Hymenoxys, sendo as espécies mais utilizadas Gaillardia megapotamica var. megapotamica (Spreng.) Bak.; G. megapotamica var. scabiosoides (Arn.) Bak.; G. megapotamica var. radiata (Griseb.) Bak.; Helenium donianum (Hook. \& Arn.) Seckt; H. argentinum Ariza e Hymenoxys anthemoides (Juss.) Cass. Neste trabalho, foram estudadas as relações entre os táxons mencionados a partir do ponto de vista morfológico, a sua coexistência em populações naturais e suas ações farmacológicas reputadas. As suas características histológicas são descritas e ilustradas, a fim de obter uma exata identificação botânica dos produtos encontrados no mercado, de forma a garantir a sua qualidade, especialmente porque as amostras são freqüentemente já pulverizadas ou em pó.
\end{abstract}

Unitermos: Medicina popular, Asteraceae, Helenieae, botões d'ouro, estudos farmacobotânicos, utilizações etnofarmacológicas.

\begin{abstract}
The aerial parts of six Argentinean plants - commonly known as "botones de oro"are indistinctly used either in folk medicine or to obtain herbal remedies and phytotherapics. However, these entities belong to three different genera of the Tribe Helenieae (Asteraceae): Gaillardia, Helenium and Hymenoxys, being the most used species Gaillardia megapotamica var. megapotamica (Spreng.) Bak.; G. megapotamica var. scabiosoides (Arn.) Bak.; G. megapotamica var. radiata (Griseb.) Bak.; Helenium donianum (Hook. \& Arn.) Seckt; H. argentinum Ariza and Hymenoxys anthemoides (Juss.) Cass. In this work, we studied the relationships between the mentioned taxa from the morphological point of view, their coexistence in natural populations and their reputed pharmacological actions. Their histological features are described and illustrated, in order to obtain an accurate botanical identification of the products found in the market so as to guarantee their quality, especially because the samples are often already powdered or grounded.
\end{abstract}

Keywords: Argentinean folk medicine, Asteraceae, Helenieae, "botones de oro", pharmacobotanical studies, ethnofarmacological uses.

\section{INTRODUCTION}

The Asteraceae is the family of plants whose individual flowers are arranged in capitula. It includes the widest diversity amongst the plant families, comprising 1,620 genera distributed in 30 tribes and c. 22,750 species (Mabberley, 1997), many of which have had undeniable importance in ethnomedicine from ancient times (Del Vitto et al., 1997; Barboza et al., 2006; Agra et al., 2007 and 2008).

Thirteen tribes of the Asteraceae family (represented by 222 genera and 1,490 species) grow in Argentina. The tribe Helenieae is represented in Argentina by 12 genera with 41 specific and infraspecific taxa (Petenatti, 1995; Petenatti \& Ariza-Espinar, 1997) with high endemism degree. Six taxa belonging to the Tribe Helenieae are known under the popular name of "botones de oro" ("golden buttons") and used as folk medicine in Argentinean and boundary countries like Brazil and Uruguay: Gaillardia megapotamica (Spreng.) Bak. var. megapotamica; G. megapotamica var. scabiosoides (Arn.) Bak.; G. megapotamica var. radiata (Griseb.) Bak.; Helenium donianum (Hook. \& Arn.) Seckt; Helenium argentinum Ariza and Hymenoxys anthemoides (Juss.) Cass. (Del Vitto et al., 1997; Barboza et al., 2006).

Since these entities present a narrow morphological similarity, that their populations coexist 
in the natural conditions and they are known with the same vulgar name "botones de oro", this study was carried out to register its popular applications and to characterize commercial products of derived them, contributing to the determination of the botanical composition and to the certification of its quality, mainly when they are sold ground out or reduced to powder.

\section{MATERIAL AND METHODS}

\section{Ethnopharmacological data}

The ethnopharmacological data proceed of two sources: 1. The ethnomedical interviews carried out from some healers and regional merchants; and 2. ethnobotanical and ethnopharmacological bibliographical references.

The ethnobotanical interviews were carried out in several visits to field to "connoisseurs" made between the years 1990 and 1997. A total of 30 informants was interviewed using an interview semistructured according to Cotton (1996). The frequent questions were made on the use of the plant, leaves from the used plant, form of attributed preparation and use/s to the same ones in traditional medicine. Greater informants of 60 years selected themselves by virtue of which they were those that had the greater knowledge about the ethnopharmacological use.

The ethnomedical and ethnopharmacological bibliographical references were obtained from Barboza et al. (2006), Del Vitto et al. (1997), Núñez \& Cantero (2000), Petenatti (1995), Steibel (1997), Bustos et al. (1996), Roig (2001), and Toursarkissian (1980).

\section{Plant material}

The reference material of the plants was gathered in company of qualified informers and their vernacular names were registered in each case. The collected material was identified by the authors and they are deposited in the Herbarium of the National University of San Luis (UNSL).

The aerial parts from these species were collected in the cities of Mendoza and San Luis, in the central-west region of Argentina or obtained from markets in the city of San Luis, Argentina. The following are the vouchers of such species:

Gaillardia megapotamica (Sprengel) Baker var. megapotamica - Del Vitto et al. 5825, San Luis Province: Pringles Department, near La Carolina, January 15, 1991.

Gaillardia megapotamica var. scabiosoides (Arn.) Baker - Del Vitto et al. 4592, San Luis Province: La Capital Department, San Luis city, December 28, 1989.

Gaillardia megapotamica var. radiata (Griseb.) Baker - Del Vitto et al. 7085, San Luis Province:
Ayacucho Department, $4 \mathrm{~km}$ east of L.N. Alem, $620 \mathrm{~m}$ above sea level, March 3, 1993.

Helenium argentinum Ariza - Del Vitto et al. 5499, San Luis Province: La Capital Department, crossroads of provincial road 20 and Aguada de Pueyrredón, December, 1990.

Helenium donianum (Hook. \&Arn.) Seckt Del Vitto et al. 9373, Mendoza Province: Uspallata december 2005.

Hymenoxys anthemoides (Juss.) Cass. Del Vitto et al. 7454, San Luis Province: Belgrano Department, La Calera, km 784, gully of the creek, October, 1992.

\section{Methodology}

Plant material was fixed with formalin:acetic acid:ethyl alcohol (1:1:1) and analyzed exomorphologically and anatomically. Diaphanization (Dizeo de Strittmater, 1973) and quantitative micrographic techniques were applied. On the other hand, some materials were included in paraffin (Johansen, 1940), stained with safranin-fast green and mounted in DPX (D'Ambrogio, 1986). In the micrographic techniques, the following parameters were obtained: stomata number ( $\mathrm{SN}$ ) in the two epidermis (stomata. $\mathrm{mm}^{-2}$; Timmerman, 1927); stomata ratio among hypophyllum and epiphyllum (SR); stomata index (SI; Salisbury, 1927); palisade ratio (PR; Zornig \& Weiss, 1925); vein-islet number (VIN, islets. $\mathrm{mm}^{-2}$; Levin, 1929) and veinlet termination number (VTN, terminations. $\mathrm{mm}^{-2}$; Hall \& Melville, 1951), they were measured using a 20x objective (except for SN, with a 40x).

The microscopic observations as well as measurements and drawings were obtained by means of a Leitz DMRB optical microscope with drawing device, while the macromorphologic observations were made with a Leica M-10 stereomicroscope; in both cases, the photomicrographs were taken with a Leica interchangeable photographic device.

\section{RESULTS AND DISCUSSION}

\section{Ethnopharmacological uses}

The three varieties of Gaillardia megapotamica - especially their heads (capitula) - are used indistinctly as anticephalalgics, antineuralgics, antiseborrheics and antialopecics and against influenza and congestion and as infusions or decoctions for internal or external use respectively (Barboza et al., 2006; Hieronymus, 1882; Toursarkissian, 1980; Del Vitto et al. 1997; Steibel, 1997; Núñez \& Cantero, 2000; Roig, 2001).

On the other hand, the aerial parts of Helenium argentinum is reputed as a digestive (Del Vitto et al., 
1997) and Helenium donianum as an anti-asthmatic, decongestant and stomachic (Roig, 2001), while the aerial parts of Hymenoxys anthemoides are used to treat catarrh and cephalalgia in popular medicine but there is some data about their toxicity in cattle (Ragonese \& Milano, 1984; Núñez \& Cantero, 2000). The scientific and vernacular name, synonymy, habit, plant part used and ethnopharmacological data on some Gaillardia, Helenium and Hymenoxys species from Argentina are summarized in Table 1.

\section{Morphoanatomic features}

\section{Genus Gaillardia}

Morphological features: Although these species are closely related from the morphological point of view, they can be distinguished especially by their receptacles. In fact, Gaillardia has rigid setaceous bristles, while the other species have smooth receptacles devoid of bristles.

G. megapotamica is a geophyte with gemmiferae roots to hemicryptophyte; aerial stems herbaceous, tending to be woody, growing up to 60 $\mathrm{cm}$ tall, densely leaved in the lower part, glandulosepubescent, with alternate, lanceolate leaves, attenuating towards the base into a long petiole; the blade with an entire to lobate margin, bright green; the capitula are discoid, lonely in the apex of long aphyllous scapus, erect or flexuose, with hemispheric involucre with linear to lanceolate bracts, reflected in the fructification and the convex receptacle provided with conic and stiff bristles. The flowers are hermaphrodite and yellow. The turbinate achene has a red-brown and thick pubescence and a paleaceous pappus with 7-10 bidentate pieces.

G. megapotamica var. scabiosoides: The morphological differences with $G$. megapotamica var. megapotamica are the pinnatisect leaves and the foveolate receptacle surface because the bristles do not joint in the base.

G. megapotamica var. radiata: The typical variety differs by the radiate capitula and the toothed up to lobated leaves from the scabiosoides variety.

Anatomical features: The genus Gaillardia shows a unistrate epidermis with a strong cuticle. While the epidermal cell walls of G. megapotamica var. scabiosoides are irregular and sinuous, the other taxa of the genus have polyhedrical ones with smooth walls varying in size and form. The stomata of all entities are anomocytic or ranunculaceous (Metcalfe \& Chalk, 1950), while the indument is formed both by eglandular (2-5 celled with a sharpened elongated apical cell) as glandular trichomes densely spread on leaves and inflorescence. The glandular trichomes are usually placed in a depression due to invaginations, with a 2-celled head, sessile or with 1-2 celled stalks. Both types of trichomes are present in the hypophyllus and epiphyllous leaves, on the stems and inflorescences.

The leaves structure show their isolateral mesophyll with various layers palisade parenchyma towards both surfaces, while the center of the leaf structure is occupied by a loose spongy parenchyme. The vascular bundles are collaterally arranged; in the midrib they are protected by three or four layers of angular collenchyma towards both surfaces, while the lateral ones are immersed in a fundamental parenchyma.

The transverse section through ribbed stems shows a unistrate epidermis with a thick cuticle and simple eglandular and sessile glandular trichomes, while the cortex is formed by fundamental parenchyma that takes collenchyma in the angles. Usually the endodermis is darkly defined. The pericycle always including sclerenchyma, being the latter most frequent in the form of crescent-shaped strands at the outer boundary of the phloem groups of the vascular bundles. Some cortical vascular bundles are present, and the pith cells are thin-walled (Figure 1). The herbaceous stems show a single ring of collateral vascular bundles.

\section{Genus Helenium}

Morphological features: $\boldsymbol{H}$. argentinum is an erect subshrub with pubescent striate stems. The leaves are linear, entire and glandulous. Radiate single head on long naked peduncles. The hemispherical involucre is covered with biserial bracts minutely pubescent. Flowers are dimorphous, yellow covered with gold-plated glands. Turbinate achenes, brown, with paleaceous pappus constituted by $8-11$ acute, acuminate bristles, finished in an awn that exceeds the corolla.

H. donianum is a subshrub with many branches. The leaves are sessile, linear or lanceolated, usually entire. Radiate single head on long peduncles. Hemispherical involucre is covered with biserial bracts. Flowers are dimorphous and yellow. Turbinate achenes, brown, with paleaceous pappus constituted by 5-7 acuminate bristles, finished in an awn that exceeds the corolla.

Anatomical features: The Helenium shows similar anatomical characters from the Gaillardia in the epidermis, stomata, the indumenta and the structure of leaves and stems, but the endodermis shows a well defined starch sheath.

\section{Genus Hymenoxys}

Morphological features: $\boldsymbol{H}$. anthemoides is an annual herb with ascendant or decumbent stems, 10$20 \mathrm{~cm}$ high, with pinnatisect or bipinnatisect leaves of narrow-linear segments. The heads are single, discoids, sparingly pedunculated, with globose involucre covered by biserial ovate, obtuse bracts. The receptacle is convex, glabrous. The flowers are isomorphic, tubulous and yellow. The hairy achenes show a pappus constituted by 


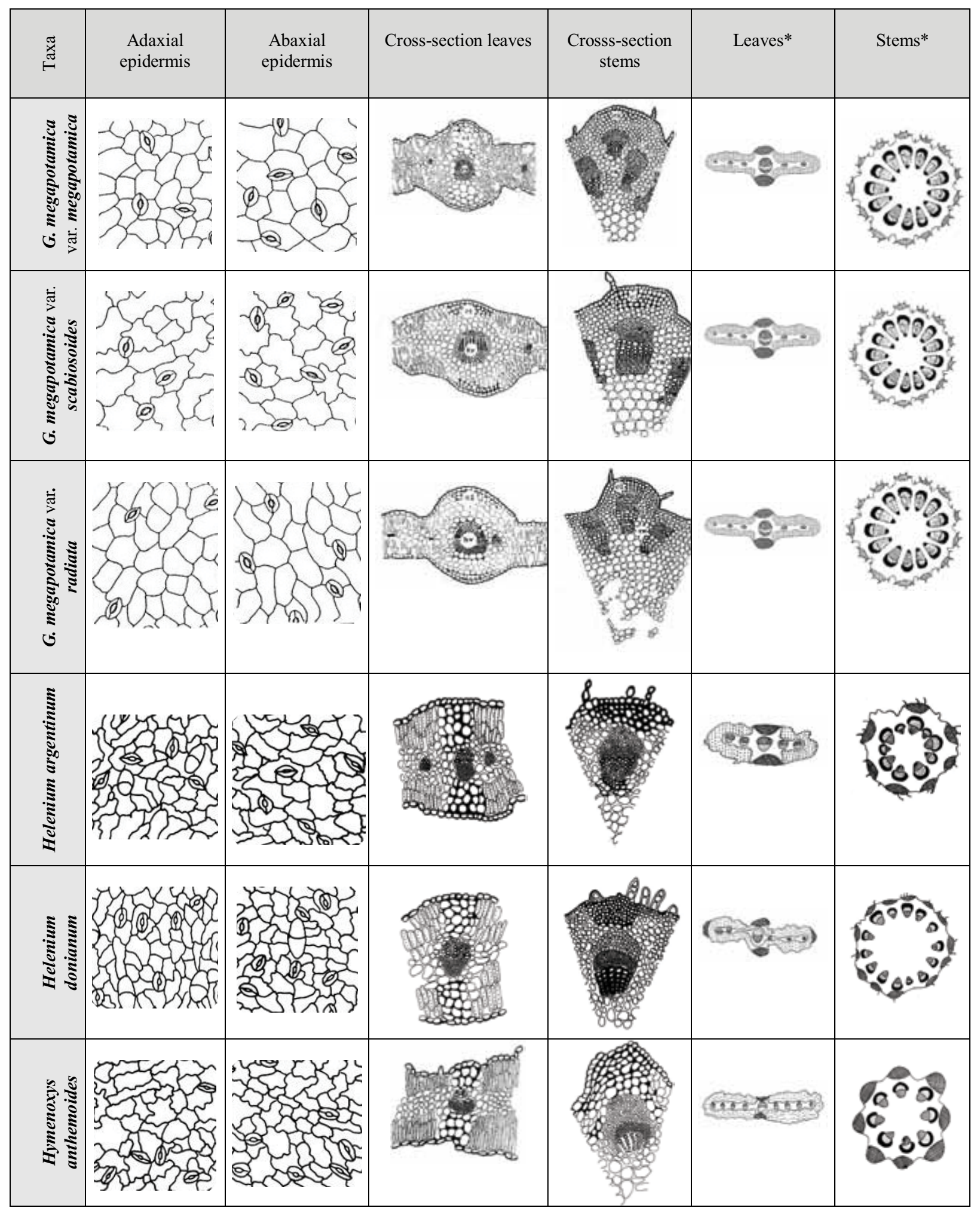

Figure 1. Comparative anatomical features on "botones de oro" of the medicinal folk in Argentina (* symbology after Metcalfe \& Chalk (1950) modified). 


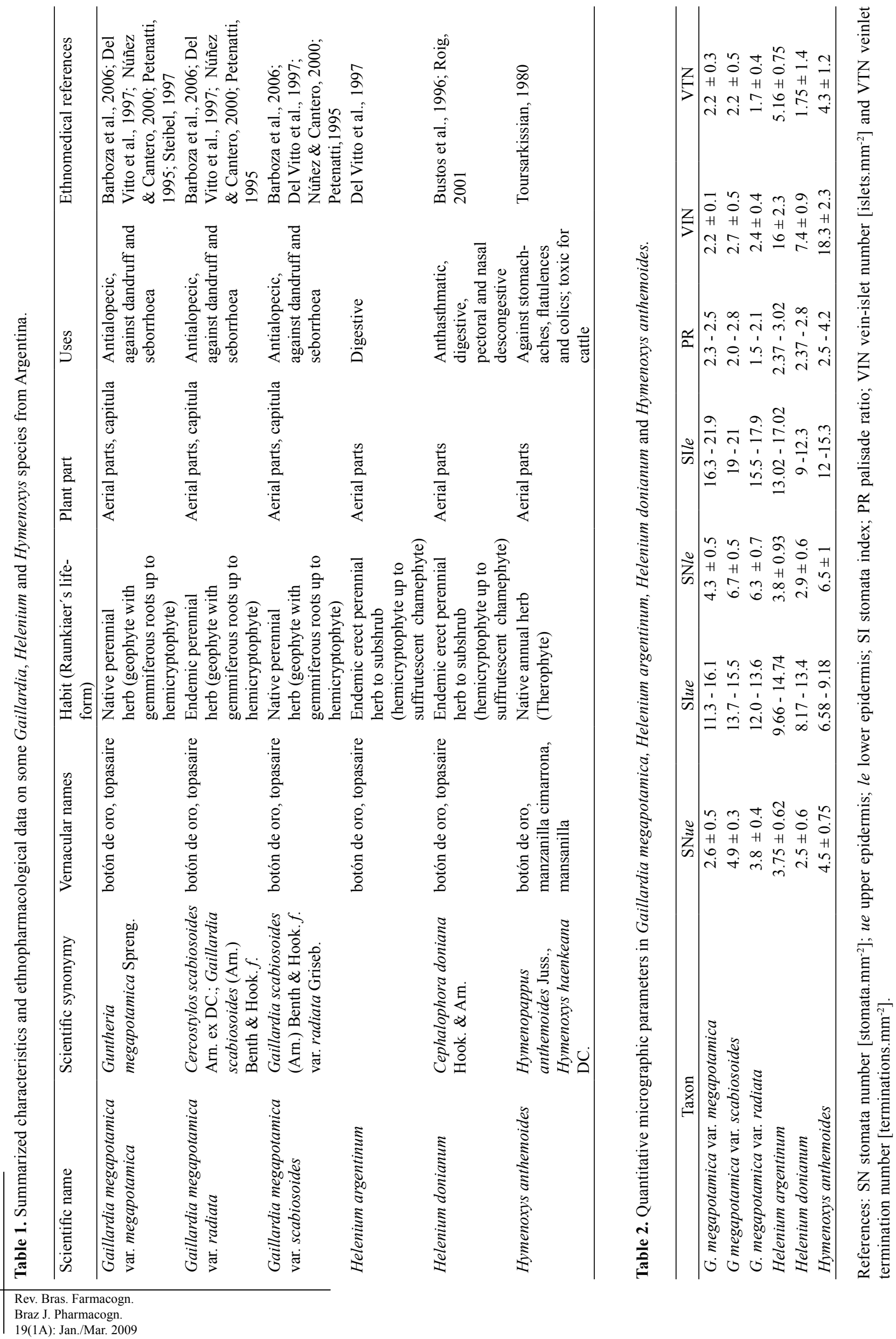


5-7 hyaline bristles, aristate in the apex, equal or longer than the corollas.

Anatomical features: The Hymenoxys shares the same anatomical characters of the Gaillardia and Helenium in the epidermis, stomata, the indumenta and the structure of leaves and stems, but the endodermis shows a well defined thick starch sheath. The herbaceous stems show a single ring of collateral vascular bundles. The cortical vascular bundles are present. The pith often consists of thin-walled cells (Figure 1).

\section{Micrographic evaluation}

These entities are differentiated by the values of micrographic parameters, which can be detected even when they are moltured, crushed or reduced to powder as they are usually found when integrating herbal or phytotherapic formulations. The quantitative micrographic parameters are summarized in Table 2.

\section{CONCLUSIONS}

The present study showed the variation of morphological features and especially the values of the micrographic parameters for three varieties of Gaillardia megapotamica, Hymenoxys anthemoides, Helenium donianum and $H$. argentinum. Thus, the infrageneric taxa of Gaillardia are easily distinguishable by their paleaceous receptacle, while the receptacles of Helenium and Hymenoxys do not have paleas. At a microscopic level, minor differences are observed.

The values of the micrographic parameters are interesting because the three varieties of $G$. megapotamica can be distinguished by the stomata number in both epidermis and the stomata index, while the vein-islet number and vein termination number present significant differences among the evaluated species of the three diverse genera.

We hope that these studies will lead to the correct use of each "botones de oro" in the traditional Argentinean medicine and at the same time, that it will facilitate the quality control of the commercial products which are out in the market under the vernacular name of "botones de oro".

\section{ACKNOWLEDGEMENTS}

The authors wish to thank the Secretaria de Ciencia y Técnica, Universidad Nacional de San Luis for their financial support (Project 2-4-8702). MAG wishes to thank CONICET for its fellowship. SAZ wishes to thank ANPCyT (PICT R 260).

\section{REFERENCES}

Agra MF, França PF, Barbosa-Filho JM 2007. Synopsis of

\footnotetext{
the plants known as medicinal and poisonous in
}

Northeast of Brazil. Rev Bras Farmacogn 17: 114140.

Agra MF, Silva KN, Basílio IJLD, França PF, Barbosa-Filho JM 2008. Survey of medicinal plants used in the region Northeast of Brazil. Rev Bras Farmacogn 18: 472-508.

Barboza GE, Cantero JJ, Núñez CO, Ariza Espinar LA 2006. Flora medicinal de la provincia de Córdoba (Argentina). Córdoba, Museo Botánico.

Bustos D, Tapia A, Feresin G, Ariza Espinar L 1996. Ethnofarmacobotanical survey of Bauchazeta district, San Juan Province, Argentina. Fitoterapia 67: 411-415.

Cotton CM 1996. Ethnobotany. Principles and Applications. England, Wiley.

D’Ambrogio A 1986. Manual de técnicas en histología vegetal. Buenos Aires, Ed. Hemisferio Sur.

Del Vitto LA, Petenatti EM, Petenatti ME 1997. Recursos herbolarios de San Luis (Argentina), Primera parte: plantas nativas. Multequina 6: 49-66.

Dizeo de Strittmater C 1973. Nueva técnica de diafanización. Bol Soc Argent Bot 15: 126-129.

Hall JP, Melville C 1951. Veinlet termination number, a new character for the differentiation of leaves. J Pharm Pharmacol 3: 934-941.

Hieronymus J 1882. Plantae diaphoricae florae argentinae. Bol Acad Nac Cienc 4: 352.

Johansen DA 1940. Plant microtechnique. New York, McGraw-Hill Ed.

Levin FA 1929. The taxonomic value of vein islet areas based upon a study of the genera Barosma, Cassia, Erythroxylon, and Digitalis. Quart J Pharm 2: 17-43.

Mabberley DJ 1997. The Plant Book. A Portable dictionary of the Vascular Plants. Cambridge, Cambridge University Press.

Metcalfe CR, Chalk L 1950. Anatomy of the Dicotyledons. Leaves, stems and wood in relation to taxonomy, with notes on economic uses. Oxford, Clarendon Press.

Núñez C, Cantero JJ 2000. Las plantas medicinales del Sur de la provincia de Córdoba. Río Cuarto (Córdoba), Ed. Fundación Univ. Nac. Río Cuarto.

Petenatti EM 1995. Estudios morfológicos y quimiotaxonómicos en especies argentinas de la Tribu Helenieae (Asteraceae - Asteroideae). San Luis, 210 p. Tesis Doctoral- Universidad Nacional de San Luis, Argentina.

Petenatti EM, Ariza Espinar L 1997. Asteraceae. Tribu IV. Helenieae. In: Hunziker AT, Flora Fanerogámica Argentina, 1.ed. Córdoba: Museo Botánico IMBIV fasc. 45 : p. 1-34.

Ragonese AE, Milano VA 1984. Vegetales y substancias tóxicas de la Flora Argentina. Buenos Aires, Ed. Acme.

Roig FA 2001. Flora medicinal mendocina, Las plantas medicinales y aromáticas de la provincia de Mendoza (Argentina). Mendoza, EDIUNC.

Salisbury EJ 1927. On the causes and ecological significance of stomatal frequency with especial reference to the woodland flora. Phil Trans Roy Soc London B 216: $1-65$.

Steibel PE 1997. Nombres y usos de las plantas aplicados por los Indios Ranqueles de La Pampa (Argentina). Rev Fac Agron Univ Nac La Pampa 9: 14-15.

Timmerman HA 1927. Stomatal number: their value for distinguishing species. Pharm J 118: 241-243.

Toursarkissian M 1980 Plantas Medicinales de la Argentina. Buenos Aires, Ed. Hemisferio Sur.

Zörnig H, Weiss G 1925. Beiträge zur Anatomie des Laubblattes offizineller und phärmazeutische gebräuchlicher Compositen-Drogen. Arch Pharm 263: 451-470.

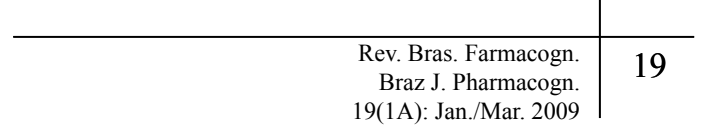

